Abstracta Iranicacta Iranica

Revue bibliographique pour le domaine irano-aryen

Volume 26 | 2005

Comptes rendus des publications de 2003

\title{
« TārīH̆-e sorūde-šodan-e do ġazal-e Ḥāfeẓ ». Našr-e Dāneš, 20, 1 (1382/2003), pp. 17-18.
}

\section{Charles-Henri de Fouchécour}

\section{(2) OpenEdition}

\section{Journals}

Édition électronique

URL : http://journals.openedition.org/abstractairanica/1858

ISSN : 1961-960X

Éditeur :

CNRS (UMR 7528 Mondes iraniens et indiens), Éditions de l'IFRI

Édition imprimée

Date de publication : 15 mai 2005

ISSN : 0240-8910

\section{Référence électronique}

Charles-Henri de Fouchécour, « «Tārīh-e sorūde-šodan-e do ġazal-e Hāfez ». Našr-e Dāneš, 20, 1

(1382/2003), pp. 17-18. », Abstracta Iranica [En ligne], Volume 26 | 2005, document 350, mis en ligne le 07 décembre 2005, consulté le 25 septembre 2020. URL : http://journals.openedition.org/ abstractairanica/1858

Ce document a été généré automatiquement le 25 septembre 2020

Tous droits réservés 


\title{
« TārīH Hāfez ». Našr-e Dāneš, 20, 1 (1382/2003), pp. 17-18.
}

\author{
Charles-Henri de Fouchécour
}

1 Au ġazal 164 (160 de Hูānlarī), Ḥāfez mentionne qu'il est au mois de ša'bān, qui précède celui de ramaḍān, et aussi au printemps. Il est donc aisé, en consultant un calendrier, de voir que cette coïncidence eut lieu en 738 et en 771 (mon calendrier m'indique 737 et 770 !). Dans le premier cas, le gazal serait du temps de la jeunesse de Ḥăfez, en 738/1337-8, or c'est en 744/1343 que commença le règne d'Abū Esḥāq l'Indjouide et que Ḥāfez commença à être connu. Dans le deuxième cas, en 771/1369, plus probable, on serait à la période difficile du règne de Šāh Šojā'. L'autre gazal datable est le ġazal 46 (47 de Hānlarī), où le poète dit au beyt 11 qu'il est au printemps et à la fête de clôture du ramaḍān, ce qui ouvre plusieurs possibilités, entre lesquelles il est plus difficile de choisir.

\section{INDEX}

Thèmes : 11.1.1. Littérature persane classique

nompropre Hafez, Šāh Šojā, Shah Shoja' 


\section{AUTEURS}

\section{CHARLES-HENRI DE FOUCHÉCOUR}

Fondateur de la revue Abstracta Iranica - Paris 